\title{
保加利亞科蛪院的組織、任務、計劃 和工作方法
}

現在的保加利亞科學院，是根據1949年的法

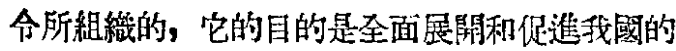

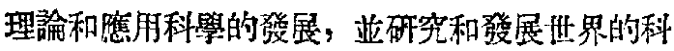
學成就，而首先是蘇聯的科學思想，以便在保加 利亞人民共和國的建設上，全面有計割地運解它 椚。

篇了達到這個目的，保加利亞科學院，把自己 的科學工作，集中到科學上各部間的、最大的利指

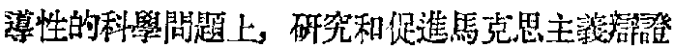
法在一切科學方面的運用和發展，在馬克思一列 察主義的基礎上，研究哲學的、社會的和民族的問 题上,特别注意到保加利亞的嫄史、交學和語言的 研究，以及我國人民在經就上和思想上的發是，有 系彩地進行反對大保加利亞的沙文主義和法陌斯 主義的、反動的世界主義的以及國队外所有其他

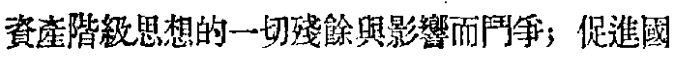
內各科學研究所和各科學機模的全部科學事業的

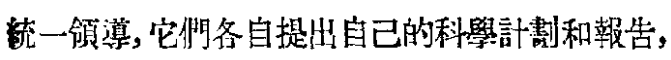
其目的是使它們計咕的科學業務與科學院的業務 配合; 研究國內的自然富源和促進國家生產力的 發展㦛提高; 從事於科學翰部的培養和幹部筫量 的提高; 在特殊重要的情况下, 坫助最涪國家的和 其他社會的機檏, 而首先要服務於那組織科祭會

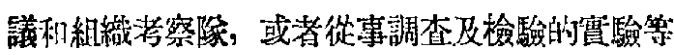
國家計劃委員會。

根按保加利亞科學院鹪法令而保在的雨大部 （即晢學一社會科學部和自然科學一數學部）和 咭多分部, 事賽上已成笘科學院所屬各科學研究 所正碓的和全面撥展的極其主要的組緟上的障 礙, 而這些研究所正是, 也鷹當是,科學院的科學 研究和科學應用工作的基柇組織形式。

現行的 1949 年的法令規定，以數目不多的部
代替兩大部和許多分部，這些新的部道當地分配 幹部和任隆, 所以，根掾保加利亞共產黨第五屆代 表大會的决議, 保加利亞科學院改組後的組織和 科學研究工作的進行, 有了更正確亚且在各方面 是更有效的可能性。

現在保加利亞科學院共有七部:

1. 物理學一數學和技街科學部;

2. 地筫一地理學和化學部;

3. 生物楽和醫學科學部;

4. 愁史學、考古學和哲學部;

5. 洗律和經濟學部;

6. 語言學、人類學和文學部;

7. 美術和文化部。

過去雨大部的主席撤鎑，而另設部的會㯰和 部的辦公宣，作篇各部的領導機丵。

每一部的领資事宜, 由辦公室執行, 辦公室 的成員中有: 秘書一是在主席園成員中由三年一 次的科學院全體大會所選舉的院士; 副秘書一 一個通䛊院士和一倜院士，或者亦是一個通讯院 $士$, 他們是在每三年的部的會議, 以出席正式院 土和通訊院士三分之二以上的大多数的投票選舉 之。

在部的組成中，在沒有院士的各部中，通訊院 士, 可選篇辦公宗秘書。

保加利亞科學院各研究所是院的科學研究和 科學㶐用工作的基本機構。

研究所的目的, 是發展保加利亞科學的各個 有關分科和促淮科學在社會主義建設中及媱我國 勞動人民的交化和生活水平的提高中的圣面有計 割的應用。

現在屬於保加利亞科學院的研究所，計有29 個; 分屬各部如下:

第入期 科學通報 
I 物理一数學和技街科學部;

1. 物理研究所;

2. 數學研究所;

3. 工學研究所。

II地質一地理學和化學部:
4. 地質研究所;
5. 地理研究所;
6. 化學研究所。

III生物移相醫學科學部:
7. 動物研究所;
8. 植物研究所;
9. 生物确究所;
10. 微生物研究所;
11. 土壤邵究所;
12. 實䮑翳學研究所;
13. 踟床和社會醫學研究所;
14. 實䮭嘼醫研究所;
15. 畜牧研究所。

IV 歷史學・考古學和哲學部,

16. 保加利亞等史研究所;

17. 搭古學研究所;

18. 檔案研究所;

19. 哲學研究所一保加利亞百科全書組;

20.教育學研究所。

V 法律敉谇學部:

21. 法學研究所;

22. 經漳學研究所;

VI 語言學・人極學和文學部:

23. 保加利亞語言研究所;

24. 人福學研究所;

25. 文學研究所;

26. 保加利亞科興院圆書管。

VII 美術交化部:

27. 音樂研究所;

28. 美術研究所;

29. 城门j建設吅建䇣研究所。

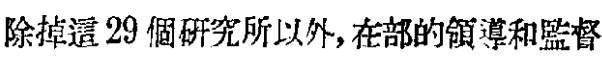

下還有六個博物管，一個重物总和一個稙物圆，另 有一個金席物博物站。

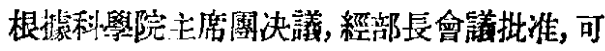
以建立新研究所。

在各研究所下面, 可以建立博物舘, 模範䁈驗
場、珼驗站、探集站，圖書筈、工廠等等。

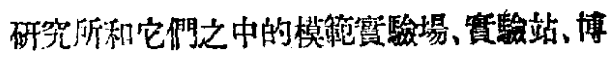
物管和其他等, 都在科學計劃和碩算的一般範圈 內, 敦有學術和經澊的獨立權。

每一研究所設一所長篇領歪, 他要親身統一 地領導研究所证担負起它全部的業務。

所長是以科學院主席團根㹉各所辦公空的提 議, 從院士、通訊院士或者是從公認的大科學家一 現代科學方汿的専家任命之。

根據科學院的顷算，研究所所長在瓷主席團 所京意的工作部劃的和給研究所所雅定的用款比 率的筑图內, 享有行政和經流上的獨立權。

在每一研究所設一學衡會櫧，該會討論研究 所的科學計劃和其計劃地完成並討論具體的科學 问题，學術會議是在研究所長領導下的諮議機 關。

學術會議的成員, 由科學院院士和通訊院士 以及著名的專家，保加利亞科學院編制內外的各 有關科學技衔、文化和國民經演各方面工作人員 所組成。學術會議的成貝由研究所長的提誘或者 “是部辦公空的䜌起由“常務委員會”决定。

研究所的所長副所長是學衙會議的主席。

“常務委員會”根譃有關部的辦公宝的建議興 研究所所長的同意，任命副所長和學街秘書，這個 秘書,同時也是研究所的學術會㦈的秘畫。

部在學術上領尊屬於硋部的各研究所，審查 和配合各研究所的工作，並視需要在它們喕前提 出一般的科學任弥，更監督科學計劃的完成。

各部每年年終向科學院主席團提呈本身科學 事業的總報告。

集體有計劃的研究，是保加利亞科學院科學 研究與科學應用工作的基本形式，蕜且還鼓捱院 士、科學院全體工作人員和科學院以外的科學家 的個人的、創作的、理論與科學應用的主動綪神。

保加利亞科學院召集科學品題和科學㬏劃及及 其計劃完成的討論會，召集科學代表大會和學街 評議會, 並與國內外各科學機静和學術團體的, 首 先是與蘇䏉和其他人民民主國家機構的保持聯

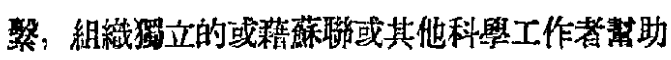
的科學研究考察隊, 在自己的期刊、選集和書刊 中，出版本院院士和其他科學工作者的著作。

保加利亞料學院在經部長會萭批准的科學院 
科學計舦範園內，有計劃地貫徹自己的科學研究 和科學應用事業。部長會議每年責成这個計劃的 完成。

中!於科學院造程工作計劃的組織㤬，可以看 出科學院院士和通訊院士的腹孜，在自己這一方 面，在適合於科學院科學研究計敖之下，形徽他們 自己的工作，並向科學院提出自己的業務報告，啨 極地參加科䋰院全䯏大會和各部會議以及學街會 議的討論會的工作。

院士和通訊院士必须完成科學院所委社在他 們身上的任伃，還要參加科學院科學幹部的唔㑢 工作，對這個工作，保拁利亞科學院也完全感到椒

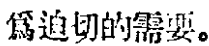

現行的1949年保加利亞科學院的法令一方面 品城利、學院的科學和全部事業在與我國社會主義

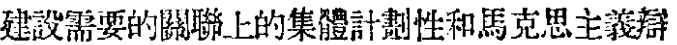
證法的特徵; 另一方面，科學院各管理機丵的責

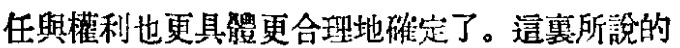
不嚾是對全體大會、主席㯖和常務委員會, 而且是 各部和各所的管理機構。

保加利亞科學院的主管瀊關有: 全體大會、主 席團和常侈委員會。

除掉年度垠告大會以外，每年間，根掳主席團 的决定，可以召集定期的、蹈時的、紀念性的和其 他會議。

全體大會第保加利亞科學院最高的領導機 關。

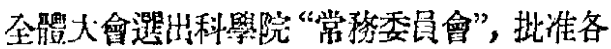

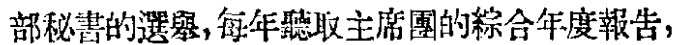
蓝對科學院過去一年中的工作予以盗; 通過主 席國關於科醮院的科學計劃和一切理論與應用 的，組蟣與行政工作的報告，决定新分部的設立，

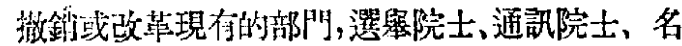

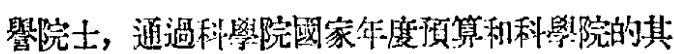
他基金,討論比較一般性的科學問題（這些阿題不 僅筑主席團提出，䨿且的院上和通訊院士提出，但 事先應以書面和動議的方式提交常務委員會)，道 過一切規章及選舉編輯一出版委員會。

科學院主席團由“常務委員會”和各學術部的 秘畫組成。

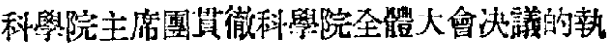
行, 同時在全體大會的休會期間, 它是科學院最高
領導機關，䒚關於自己的活動在下屆全體大會上 做報告，以科學院法令中所指示的力法監督科學 院的方針和任務的正確赛現; 編製和完成科學院 的䃌算，分配䋑费和監督他們的開支; 擬定科學院 總的科學計劃和茟設計劃以及出版討劃，提交全 能大會通過，並領導其執行；召集和領導科學院 至體大會, 確定大會日程。當學術秘書和主席疄的 其他成員，由於疾病或者其他原因阻碍自己荧䧄 的完成時，主席團任命在全體大會之前的暫洔代 理人，苝在預先得到部長會議方面的同意後，决 定關於在保加利亞科學院的組織中設吉新的科學 研究所, 博物踪和其他管等。

保加利亞科學院“常務委员”由院長，雨位副 院長和科學院學術秘書組成，他們都是以每五年 一次的科䀢院全鳁大會，在出席的院士和通訊院 士數量的三分之二以上的大多數的㐤接和秘密投 票選舉方法選出的。

“常猪委員會”可以處决緊急的問題，但需把 逻些問題提交下屆主席疄會議上, 加以追認。

“常務委員會”的會議，由科學院院長召集之， 他也確定會議的議事日程。

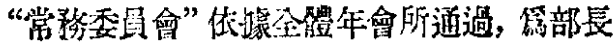
會議批准的预筧，掌管科學院的财座和基金; 組 織代表會,委員會和特殊學術門題委員會,經濟妾 化問題委員會，首先是經済資源和國家生產力的 研究委員會; 由自己的發起或者根㨜部和研究所

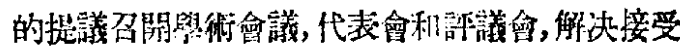
委託的問題利確定及保持與我門國队和國外的科

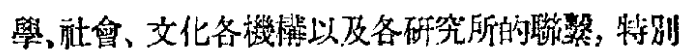

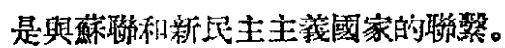

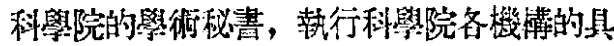

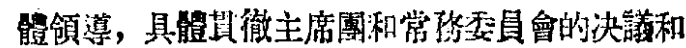
院長的指令。

保加利亞科學院的成員是:（1)院士，(2)國 內外的通訊院士，(3) 名譽院士。

科學院的成員，按其自己的尃長，分配在科學 院現有的七部队。

目前院士的數量已荙 42 人, 通訊院士 37人, 可是法令詐可院士人數增加到 72 人, 通訊院士 增加到 80 人。

凡對科學、技術、藝街、文化，特别是對社會主 義建設有意義重大的創作和發現者，得被選䉆院 
士。

凡以具有全世界意義的基本著作或發明, 圄 富了科學、藝衔、技術和文化者，或䍈保加利亞及 世界的社會主義, 玩會主義建設文化事業作了特 莂煩获者, 得被選第名譽院士。

凡有重要的，創作的科學、䘭衙、技術和一般 交化著作或發明者,表現了他們在科學院,在符合 施會主義建設方向上的基本方針、任称和方法的 精神下, 能有豐富的工作能力, 得被選䉆通訊院士。

其他國家的人，凡符合上逑一切條件，同時又 在本國人民和保加利亞人民的友誼方面，表現了 皘殹涯動者，得被選篇通訊院士。

當院士和通訊院士缺额㭙, 由大會以選舉方

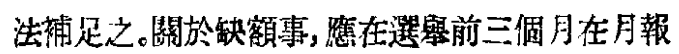
或人民會議主席團营報上宣作。

科學機關和科學學會、计會和文化围钽以及 调别的科學工作人員, 都能以報告方式提出候選 人。

經保加利亞科學院主席樯准許那些人祭候選 瓷格後，便把假選人姓名公作在刊物上。

所有被列入篇有院士及通訊院士的候潠资格 者, 在有關的各部進行篦查, 該部根據雨個審枉者 的報告, 由該部成員一院士和通訊院士的總投票 選舉之，依常例多數闹意後再把逪些候選人提議 到主席團，提交科學院全體大會上討諭。

這些候選人由全體大會選舉之，該候選人在 投票選舉方式中，至少礁獲得出原三分之二的投 票, 阙時通訊院士的通訊院士投票選舉, 而正江院 士嚾内院士投票選舉。各部和全體大會的投整選 缼取遖接的秘湾的方式。

名譽院士由主席團提名，並在全體大會上以 直接和秘密的投票方式, 以出席大會的科學院院 士三分之二大多敖的投票表决之。

僬了達到清洗科學院中公開敵對的以及已表 現沟有工作能力的院士和通訊院士的目的, 保加 利丝科罗院現行的 1949 年法令, 明交規定須把他

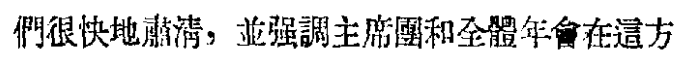
面的資任。

保加利亞科學院, 有了在科學院科學研究所

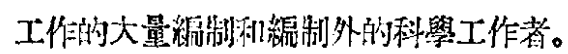

緛制內的科學工作者有: 青年科學工作者(分 篇三級)，高級科學工作者(分学二級)。

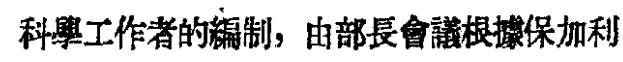
亞科擧院主席固的提議批准。

雼了使全部科學院的工作，各攵政符機關和 國內其他科學研究所的科學研究和應用工作更緊 密的聯嗸,在現行1949年的法令中,準備使科學院 的工作與政府機開和其他研究所的工作更祭滵而 更畺實的配合，同時這些研究所低然是受有變的

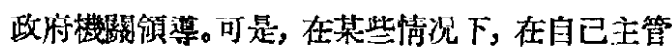
機關的同意之下，它們可以而且應當把個別的問 題列入科學院的科學研究和科學磼用計劃的制定 與實行中。

保加利亞科學院出版自己的年鑑、雜誌、選 集、百科全書、鲜典、個别的科學著作、或內和外國 出名的科學家、作家、吾樂家等學的學街刊物，還 出版通俗的科學著作。

科學院所屬的機潔, 每個研究所和各部, 出版 自己的刊物。已出版了植物學、動物學、物理學、教 育學、醫學等研究所報告。這些刊物中的某些著 作, 會在蘇証雜誌上博得好部。

在科學院的刊物上，刊載有功績的或者有代 表性的蓝第人䝷許的科學著作、初步的報告、科學 著作的諳諭、關於新院士選舉的報告等等。

䉆了增强科學院科學研究工作中的計劃珄, 效能和責任感，1949年的法令規定科笶院以糄龫

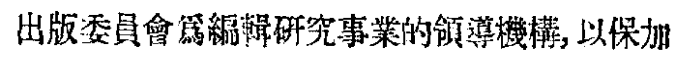
利亞科學院院長任主席，委員则根拈科學院全顝 大會的决議，以常例的大多數及秘密投票表决選 藇之。

最近㙨年來，保加利亞科學院紈著地增加了 書籍的出版。

的全部上面所說很䫏明地看出，保加利亞科 學院幾乎包括了全部自然科學和社會科學, 交舉、 美術和害樂也包括在內, 可是還有到多科學分科,

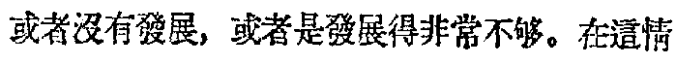
况下的有農業的，技術的和醫學科學的許多學科。 許多科學研究所中，還缺少必要的科學和技街翰 部, 而主要的是浔有必要的設備基礎能够更有效 地担鱼起社會主義建設的需要。可是, 當馬歇爾化 的國家科學家們正申訴他椚對科學研究工作狧算

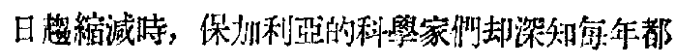
給他們以足够俉越的科學工作佟件。

除掉已完成了索非亞大學，國立“斯大林”工 
科大學，契爾交科夫醫學科學院外科治燎院的建 築以外，政府刃在 1951 年就撥發䤠款給保加利亞

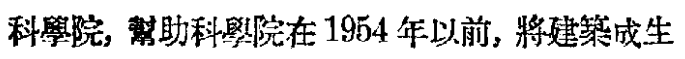
物和慜學部各研究所大量舒適和寬大防舍的延築 物。

當然, 在那樣存利的工作條件下, 保加利贸科

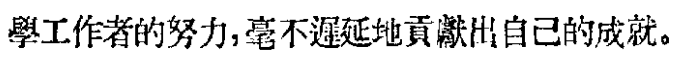
這些成就對科學的發展和社會主義建設是很重要 的。

保加利恶科學家們，首先彷效他們的蘇聯同

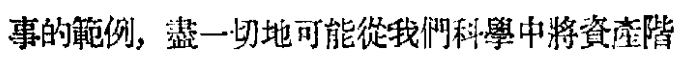

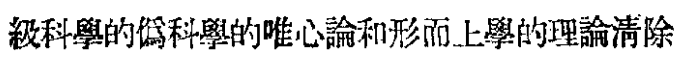
出來。基於保加利亞共黄黨的䞳助，在高等學校而 特别是在保加利亞科學院管舉行了部多次關於普 式庚、X.P. 博切夫、U. B. 正位夫，正維洛夫、米 邱林生物學、蓄牧學、斯大林“論正克思主義與語 言學問題” 的新著作和其他等等閣題的討諭會和 座談會。

我們的科學院完全有效地掌握批評與自我批 評的方法和在自己的科學工作中更成功地運用棓

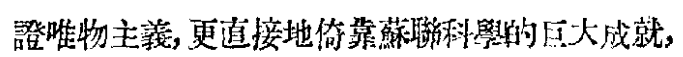
特别是在哲學、生理學、細胞學、哣言學和其他科 學討論會上的結諭, 這些討論會在䰻聯、在人民民 主國家以及奈世界，都給利學發展一個很大的刺 激。

其次，保加利亞的科學家更進一步地掌提社 會主義的科學工作方法: 任務的計劃, 集锗和綜合 的研觉，科學閔題從筫踐中得來，和理論成就迅速 地實施到生産上去。最近四年來, 我們的計割已是 更完美而目的更集中了。他們已朝向確是科學服 骆於社會主義怒梪的方向。僅僅在一個保加利亞 科學院就有二百五十多個編制队的科學工作者、 院上和通訊院士、正研究着科學院和科學院各部 以及各研究所年度和五年計劃中的詐多問題。保

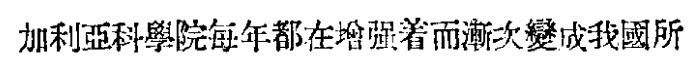
有科學研究工作的更有力的組織和配合的中心。

必須使㗐個過程能够很块地惯現, 因篇要使 保加利亞科學院辦好，成第保加利亞科學的真正 司令部是全靠它的，這樣以便于科學院能够充分、 及洔、有計港地和合理地使科學篇人民和我閒的 塥會主義建設服務。在這一方面，我們還可以向蘇 稚块科學的偉大成就學晳。
在思想上和科學組織上，唯有逼㑭保加利亞 科舉發展的正確方向，才能矽確定科學完全第我 們人民共和國經流和文化發展冒實地服務。現在， 踓然一切錯誤還是在所難免, 而許多主觀上的和 物質上的困蜼也沒克服, 但展於保加利亞科學院 的，附屬政府機䈘和高等學校的保加利亞科學工 作者和科學研究所的計劃, 直接或者是間接地都 朝向融會主蓄建設需要的方向。有許多的任務要 求直接來自生產簤姴, 或者是各部, 或者是國家計 副委員會的委哣。其他是來自國民經濟計劃，或者 由部長會議的决議, 或者由保加利亞共党黨中央 委員會關於經濟和社會建設問題的决锇。

保加利亞科學院各研究所和其他研究所的科 學工作者，特别是地荷學家、地理學家、農業生物 學家、音牧學家、士壤學家、物理學家、化學家、工 學家、細菌學家、㗨學家、嘼醫學家、動物學家、植 物學家、建築學家和其他等等, 已經或正在第工 業、農業、運輸、我國自然富源的運用、人民健康保 護和我們的文化革命的重大問題的推展和科學的 總結工作, 拿出自己的貢蹊。

保加利亞科學家正在埣助着水堤的建造, 電 力的殷計和生產，森林防護帶和護田帶的設計和 建造，土壤和水分的改良，化學的和其他工業的改 善。保加利亞科學家們正在更成功地利用米邱林 生物學的方法, 從事於耕作祜物和家畜優良品種 的創造工作。

由於保加利亞科學院的成就，而且還不斷地 在質的方面邻造科學發展和繁榮的更優越的條 件，實行了許多商品的限物輸入，這些商品現在在 我國內正由諓們自己的原料製造誉。可是在逗一 方面, 完成得還不够, 而還有許多工作要做。

我們的科學工作者不斷地向蘇聯的同志學 習,特別是,當他們來訲閶我們洔，其目的是把自 已的䁷富經驗傳授給我們，像這樣做的蘇聯科學 的著名代表們有: 葛列柯夫、馬尼柯夫斯基、瓦西 林科、棃斯塔德葉夫、托爾斯托夫、柯林科、尼古拉 棐夫，巴拉金、收格里、斯圖金尼康和培多其他的 人。

㙷然可見，保加利亞科學將是越發腪固和繁 榮了, 我椚與蘇聯科學家的聯㢣也越駸密切而誠 懇，在科學和生產工作者之間的相互。聯輀和友䛎 也越發深厚. 
耤保加利亞共產黨和黨的總書記保加利亞人 民共和國總理契爾文科夫的錦助, 並以批評與白 我批評以及創作性的討論的方法，保加利亞科學 家更多地學替着，自己揭露自己的錯㖬，也避丕犯 錯哭。我佛科學家在 1950 年和 1951 年的成就, 是

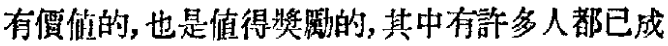
筑該雨年度的季米特洛夫獎金榮稍者。

等馬克思一恩格斯一列鼻一斯大林的偉大學

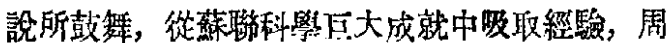

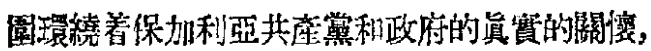
保加利严的科學家具有空前未有的熱情, 在社會 主窂的基礎上，發展、改造和建設科學，以便能够 用最優秀最及時的方法，傜社會主義侓設及孚取

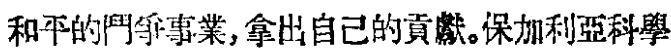
工作者意識到了社會主義的社會建築於科學的基 礎上，也理解到祇有那棣的社會，才筑科學確定下 一個光榮的地位，㫫創造了信科學迅速發展和使 科學的成就道接隹用到實跭和生活中的無限可能 性。
最後可以說, 根握保加利亞科學院 1949 年的 新法令，我國這個最高國家科學機構保障在各方 面，在最迅速的時闒內，能够發展和完成自己的全 部改革，並要重視到保加利亞人民共和國社會主 義建設的需要和要求。

保办利亞科學院，在人民民主國家科學院之 中,第一個在垌會主義的基礎上根本的改革了,保 加利亞人民有權可以騡敖, 現在有了根㹉蘇聯科 學院和䔉維埃各加盟共和國科學院的範例而發屡 的人民民主的、社會主菜類型的科學院。

我國一切科學工作者，都篇具有阙㲔和持久 工作的堅强願㘹所鼓舞着，更進一步地提高保加 利亞科學院的科學與政治思想的水平，以健在不 久的未來，真正地成第融會主義的科學院，亚埣助 保加利亞人民向着更光明更幸福的未來，實現心 块深處的期掌。

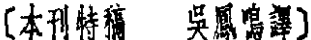

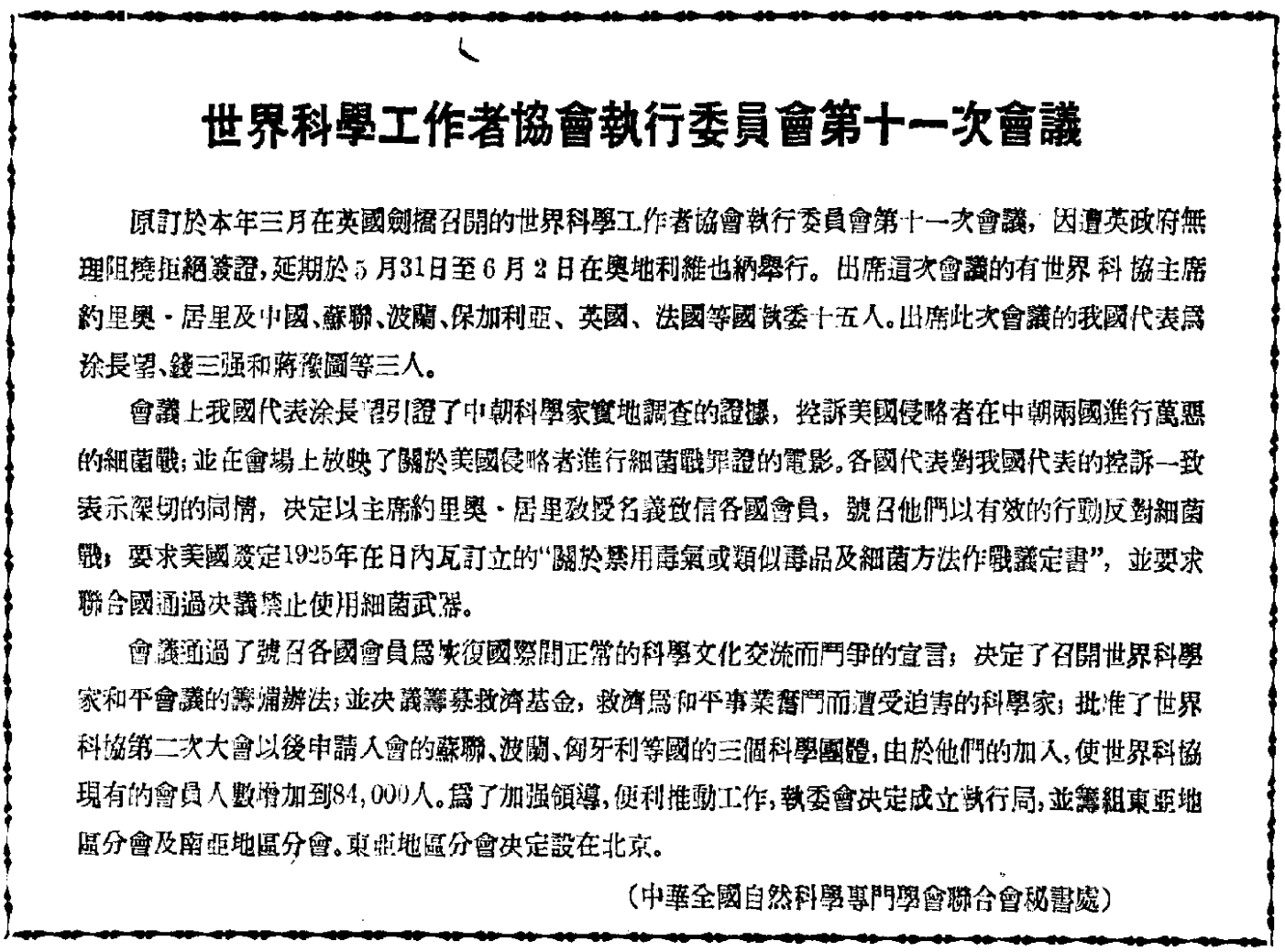

